\title{
Modifying admixtures to cement compositions produced from local raw materials
}

\author{
Daria Vasileva ${ }^{1, *}$, Egor Protodiakonov $^{1}$, Anastasia Egorova $^{1}$, and Svetlana Antsupova ${ }^{1}$ \\ ${ }^{1}$ Ammosov North-Eastern Federal University, 677000 Yakutsk, Russia
}

\begin{abstract}
Durability of hardened cement paste depends on chemical and mineralogical composition of Portland cement. The main factor for hardened cement paste is higher content of calcium aluminate and free calcium hydroxide, binding of which into water-insoluble compounds causes increase in resistance to water, frost and corrosion. The purpose of this research is to develop modifying admixtures to cement compositions based on local raw material - rock sand. Chemical and mineralogical properties of the source materials were studied using X-ray spectroscopy and X-ray diffraction analysis. Standard methods were used for defining physico-mechanical properties of sand and binder. Influence of the degree of mechanochemical activation of modifying admixture on the properties of binder and hardened cement paste made on its basis was studied. Research methods of scanning electron microscopy and spectral measurements were applied. The possibility of using admixture based on rock sand as a modifier was determined, its usage providing increase of strength, sulphate and frost resistance, which causes higher durability of cement concrete.
\end{abstract}

\section{Introduction}

Portland cement is one of the most demanded binders used for various operational conditions. In the Far East region (Russia), with its high tariffs and seasonal supply of materials, the transportation costs for 1 ton of cement is three times higher than its actual cost [1]. This fact indicates the need to search for opportunities to extend the sphere of Portland cement usage by adding in its composition mineral or complex admixtures. At the same time, the stock of local natural raw materials are abundant, they are potentially suitable for being used as admixtures to Portland cement. It is known that in production of cement with mineral admixtures specific fuel consumption is reduced by $10-35 \%$, and electricity consumption - by $12 \%[2,3]$. These data with the account of transportation costs for long-haul organomineral cement indicate relevance of the research on development of modifying admixtures to Portland cement on the basis of local raw materials.

The second direction for research is investigation of the influence of admixture on sulphate resistantce of hardened cement paste. Observations demonstrate that buildings and structures in Sakha Republic (Yakutiya, Russia) during their operation often become unfit for further exploitation prior to the schedule. This entails additional costs on reconstruction

\footnotetext{
* Corresponding author: omsvdv2910@mail.ru
} 
and construction of new buildings. It can be explained by higher content of salts $\mathrm{Na}_{2} \mathrm{SO}_{4}$ and $\mathrm{CaSO}_{4}$ in the soil. Similar problems can occur in other regions with higher soil salinity (South Kazakhstan, Middle Asia, West of the USA, South America, North Africa, in Russia - middle and southern Volga region, northeast Caucasus, south of Western and Eastern Siberia) [4].

One of the solutions to this problem can be the use of sulphate-resistant Portland cement. There were some previous studies on influence of admixtures [5] and industrial raw materials [6,7] on increase of sulphate resistance of hardened cement paste. The purpose of this study is development of modifying admixtures from mineral and organic components. Local silica raw material - rock sand - was studied as a mineral component.

\section{Materials and Methods}

Raw materials used in the research were: Portland cement of the brand ЦЕМ I 32,5 Б (M400 Д0) based on alite clinker manufactured at "Yakutcement" production plant and meeting the requirements of GOST 31108-2003 [8]; red and orange rock sand (Kildyamsky open pit, Yakutsk city); superplasticizer C-3 meeting the requirements of TU 5870-00558042865-05 [9]. Properties of Portland cement were defined according to the requirements of GOST 10178 [10] and GOST22266-94 [11]; for rock sand - according to GOST 8735-88 [12]; samples were produced from mortar and were tested according to GOST 5802-86 [13]; frost resistance of the samples was defined in compliance with GOST 10060.0-95 [14].

\section{Experiment}

The following scheme of the admixture preparation and introduction in binder was accepted for the research:

- mechanochemical activation of rock sand by milling with superplasticizer C-3 up to the optimum value of specific surface area using the laboratory ball mill Retch PM-400;

- mixing of Portland cement and activated rock sand in the laboratory mixer.

The research includes mathematical planning of factorial experiment with two variables: $\mathrm{X}_{1}$ - amount of admixture (activated rock sand), \%; $\mathrm{X}_{2}-$ rock sand activation time, min. Variation step for $\mathrm{X}_{1}-15 \%$ of Portland cement mass, and for $\mathrm{X}_{2}-2$ minutes. The following optimization parameters were applied: standard consistency of cement paste, $\%$; initial and final setting time, min.; compressive strength as the age of $14+14 / 28$ days of curing in moist cabinet, $\mathrm{MPa}$; compressive strength at the age of 14 (in moist cabinet) + $14 / 28$ days of curing in $5 \%$ solution of $\mathrm{Na}_{2} \mathrm{SO}_{4}, \mathrm{MPa}$; sulphate resistance coefficient at the age of 28 and 56 days. Equation representing dependence of optimization parameters on variable factors looks as follows:

$$
Y_{n}=b_{0}+b_{1} X_{1}+b_{0} X_{2}+b_{11} X_{1}^{2}+b_{22} X_{2}^{2}+b_{12} X_{1} X_{2}
$$

According to the accepted plan, binder compositions were prepared and beam specimens with the size of $4 \times 4 \times 16 \mathrm{~cm}$ were produced from sand-cement mortar. Having reached standard age the reference samples of each composition were cured in a moist cabinet for strength development and the experimental samples were put in sulphate environment ( $5 \%$ solution of $\mathrm{Na}_{2} \mathrm{SO}_{4}$ ). Then, after $28 / 56$ days both types of samples were tested to define the ultimate compressive strength for finding sulphate resistance coefficient. 


\section{Results}

$\mathrm{X}$-ray spectral analysis of rock sand using SRS-3400 showed the following chemical composition, \%: $\mathrm{SiO}_{2}-76.32 ; \mathrm{Al}_{2} \mathrm{O}_{3}-13.30 ; \mathrm{Fe}_{2} \mathrm{O}_{3}-6.88 ; \mathrm{K}_{2} \mathrm{O}-4.94 ; \mathrm{Na}_{2} \mathrm{O}-3.41 ; \mathrm{CaO}$ - 1.08; $\mathrm{P}_{2} \mathrm{O}_{5}-0.52 ; \mathrm{MgO}-0.37 ; \mathrm{TiO}_{2}-0.24$, etc. Rock sand samples were investigated using X-ray diffraction analysis using D8 Discover with GADDS. The following spectrum analysis results were obtained: the studied sample consists of quartz $\mathrm{SiO}_{2}-87.9 \%$ and anorthoclase $(\mathrm{Na}, \mathrm{K})\left(\mathrm{Si}_{3} \mathrm{Al}\right) \mathrm{O}_{8}-9.67 \%$. Physical properties of rock sand are given in Table 1. The sand composition is close to the research outcomes [15-16].

Table 1. Physical properties of rock sand.

\begin{tabular}{|c|c|c|c|c|c|}
\hline Title & $\begin{array}{c}\text { Bulk } \\
\text { density, } \\
\mathrm{kg} / \mathrm{m}^{3}\end{array}$ & $\begin{array}{c}\text { Specific } \\
\text { gravity, } \\
\mathrm{kg} / \mathrm{m}^{3}\end{array}$ & $\begin{array}{c}\text { Fineness } \\
\text { modulus }\end{array}$ & Void ratio, \% & $\begin{array}{c}\text { Water } \\
\text { absorption } \\
\text { capacity, \% }\end{array}$ \\
\hline $\begin{array}{c}\text { Rock sand from } \\
\text { Kildyamskoe } \\
\text { deposir }\end{array}$ & 1.03 & 2.23 & 2.73 & 52 & 8.7 \\
\hline
\end{tabular}

After that, according to the accepted plan, Portland cement samples were prepared with a rock sand admixture of various activation degree. Properties of binders and samples produced on their basis and cured in different conditions are presented in Table 2.

Results of the obtained experimental data analysis were used to make equations to represent dependences of optimization parameters on variable factors:

- for milling fineness, $\%$ :

$$
Y_{m n}=14,31+1,18 * X_{1}^{2}+0,54 * X_{2}^{2}+3,58 * X_{1}-2,66 * X_{2}-1,57 * X_{1} * X_{2}
$$

- for standard consistency of cement paste, $\%$ :

$$
Y_{s c}=24.61+0.14 * X_{1}^{2}+1.39 * X_{2}^{2}-0.685 * X_{1}+0.061 * X_{2}+0.062 * X_{1} * X_{2}
$$

- for initial setting, minutes:

$$
Y_{i s}=210-20 * X_{1}^{2}-5 * X_{2}^{2}+16.66 * X_{1}+15 * X_{2}+15 * X_{1} * X_{2}
$$

- for final setting, minutes:

$$
Y_{f s}=297.77+8.33 * X_{1}^{2}-1.66 * X_{2}^{2}+15 * X_{1}+5 * X_{2}
$$

- for ultimate compressive strength of samples at the age of 28 days:

$$
Y_{R c}=29,4-12.07 * X_{1}^{2}-2.63 * X_{2}^{2}-3.01 * X_{1}-1.49 * X_{2}-1.16 * X_{1} * X_{2}
$$

- for ultimate compressive strength of samples at the age of 56 days:

$$
Y_{R c}=35.37-14.88 * X_{1}^{2}-2.24 * X_{2}^{2}-3.45 * X_{1}-2.05 * X_{2}-2.87 * X_{1} * X_{2}
$$

- for sulphate resistance coefficient of samples at the age of 28 days:

$$
Y_{\mathrm{CSR}}=0.816+0.03 * X_{1}^{2}+0.01 * X_{2}^{2}+0.203 * X_{1}+0.016 * X_{2}-0.012 * X_{1} * X_{2}
$$

- for sulphate resistance coefficient of samples at the age of 56 days:

$$
Y_{C \mathrm{SR}}=0.808+0.02 * X_{1}^{2}-0.01 * X_{2}^{2}+0.05 * X_{1}+0.011 * X_{2}-0.007 * X_{1} * X_{2}
$$


Table 2. Results of investigation of modifying admixture to Portland cement.

\begin{tabular}{|c|c|c|c|c|c|c|c|c|c|c|c|c|c|}
\hline \multirow[b]{2}{*}{$\begin{array}{c}\text { No. } \\
\text { of } \\
\text { com } \\
\text { posit } \\
\text { ion }\end{array}$} & \multirow{2}{*}{$\begin{array}{c}\mathrm{X}_{1}, \\
\text { amount } \\
\text { of } \\
\text { admixtur } \\
\mathrm{e} \\
\text { of binder } \\
\text { mass, \% }\end{array}$} & \multirow{2}{*}{$\begin{array}{l} \\
\mathrm{X}_{2}, \\
\text { milling } \\
\text { time, } \\
\text { min. }\end{array}$} & \multirow{2}{*}{$\begin{array}{l}\text { Amount } \\
\text { of } \\
\text { superplas } \\
\text { ticizer } \\
\text { in } \\
\text { admixtur } \\
\text { e, } \%\end{array}$} & \multirow{2}{*}{$\begin{array}{c}\text { Milling } \\
\text { fineness } \\
\text { residue } \\
\text { on sieve } \\
\text { No. 008, } \\
\%\end{array}$} & \multirow{2}{*}{$\begin{array}{c}\text { Standard } \\
\text { consisten } \\
\text { cy, \% }\end{array}$} & \multicolumn{2}{|c|}{$\begin{array}{l}\text { Setting time, } \\
\text { min. }\end{array}$} & \multicolumn{3}{|c|}{$\begin{array}{l}\text { Ultimate compressive strength } \\
\text { at the age of } 28 \text { days, } \mathrm{MPa}\end{array}$} & \multicolumn{3}{|c|}{$\begin{array}{c}\text { Ultimate compressive } \\
\text { strength at the age of } 56 \text { days, } \\
\mathrm{MPa}\end{array}$} \\
\hline & & & & & & $\begin{array}{l}\text { Initial } \\
\text { setting }\end{array}$ & $\begin{array}{c}\text { Final } \\
\text { setting }\end{array}$ & $\begin{array}{c}\text { Samples } \\
\text { cured in } \\
\text { moist } \\
\text { cabinet }\end{array}$ & $\begin{array}{c}\text { Samples } \\
\text { cured in } \\
\text { sulphate } \\
\text { environ } \\
\text { ment }\end{array}$ & $\begin{array}{c}\text { Sulphate } \\
\text { resistance } \\
\text { coefficient } \\
\mathrm{C}_{\mathrm{SR}}\end{array}$ & $\begin{array}{c}\text { Samples } \\
\text { cured in } \\
\text { moist } \\
\text { cabinet }\end{array}$ & $\begin{array}{c}\text { Samples } \\
\text { cured in } \\
\text { sulphate } \\
\text { environm } \\
\text { ent }\end{array}$ & $\begin{array}{c}\text { Sulphate } \\
\text { resistanc } \\
\mathrm{e} \\
\text { coefficie } \\
\text { nt } \mathrm{C}_{\mathrm{SR}}\end{array}$ \\
\hline 1 & 0 & 4 & 0.6 & 12.10 & 26.4 & 170 & 290 & 23.23 & 19.28 & 0.83 & 28.06 & 22.17 & 0.79 \\
\hline 2 & 15 & 4 & 0.6 & 19.72 & 24.5 & 190 & 280 & 26.21 & 26.00 & 0.99 & 31.80 & 29.09 & 0.91 \\
\hline 3 & 30 & 4 & 0.6 & 23.20 & 22.3 & 170 & 320 & 18.51 & 18.99 & 1.02 & 21.02 & 19.79 & 0.94 \\
\hline 4 & 0 & 6 & 0.6 & 12.10 & 26.4 & 170 & 290 & 23.23 & 19.28 & 0.83 & 28.06 & 22.17 & 0.79 \\
\hline 5 & 15 & 6 & 0.6 & 14.28 & 25.0 & 210 & 300 & 18.52 & 17.47 & 0.94 & 25.68 & 27.54 & 1.07 \\
\hline 6 & 30 & 6 & 0.6 & 19.02 & 22.8 & 210 & 320 & 18.68 & 19.50 & 1.04 & 20.10 & 20.48 & 1.02 \\
\hline 7 & 0 & 8 & 0.6 & 12.10 & 26.4 & 170 & 290 & 23.23 & 19.28 & 0.83 & 28.06 & 22.17 & 0.79 \\
\hline 8 & 15 & 8 & 0.6 & 10.02 & 25.5 & 220 & 310 & 21.43 & 21.10 & 0.98 & 26.39 & 22.14 & 0.85 \\
\hline 9 & 30 & 8 & 0.6 & 16.90 & 23.0 & 230 & 320 & 20.36 & 22.50 & 1.10 & 24.20 & 21.86 & 0.90 \\
\hline
\end{tabular}

The obtained equations were used to build Mathcad models of dependences in the form of response surfaces. Based on the analysis of experimental data from Table 2 and and equations (2-9) the following conclusions can be made:

- Residue on sieve No. 008 increases as the amount of admixture in binder $\left(\mathrm{X}_{1}\right)$ grows, increase in time of admixture activation $\left(\mathrm{X}_{2}\right)$ causes reduction of difference between cement without admixtures and cement with maximum amount of admixture. It can be explained by high content of quartz in sand and its higher milling resistance.

- It is found that higher density of sand particles is the reason for decrease of standard consistency of cement paste as long as the amount of admixture in binder grows.

- Admixture with longer activation period have more obvious influence on the setting time, particularly on initial one, which can be explained by increase of specific surface area of the admixture and chemical activity of such elements as $\mathrm{CaO}$ and $\mathrm{Al}_{2} \mathrm{O}_{3}$. This can cause formation of initial ettringite in bigger amount.

- Ultimate compressive strength decreases almost in all cases when admixture is introduced. The exception is composition No. 2 in which rock sand activated for 4 minutes was added in the amount of $15 \%$ of Portland cement mass. This composition demonstrated increase of ultimate compressive strength by $13 \%$ compared to pure Portland cement.

- Samples are considered to be tested for sulphate resistance in case coefficient of sulphate resistance is higher than 0.8. Conducted research demonstrates that sulphate resistance of hardened Portland cement paste fails the test on 56th day of experiment, whereas introduction of admixture considerably improves this parameter.

Figure 1 presents the model of dependence for the most important parameter of the developed admixture - its effect on sulphate resistance of hardened cement paste of standard age. Analysis of the model shows that sulphate resistance of hardened cement paste is mostly affected by variation of the amount of admixture and is almost independent of milling fineness of rock sand. Based on the parameters of strength and sulphate resistance the optimum amount of admixture is $15 \%$ with its activation time of 4 minutes, which corresponds to $19 \%$ of binder residue on sieve. 


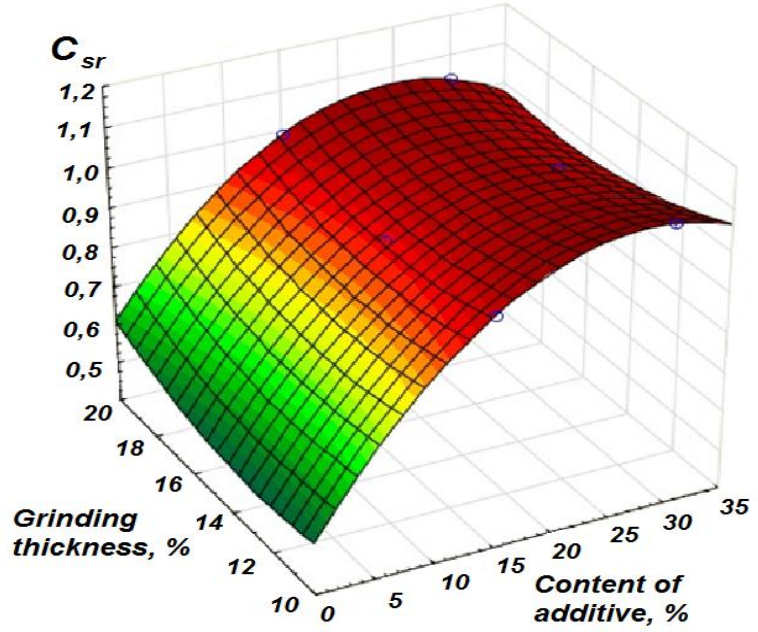

Fig. 1. Dependence of coefficient of sulphate resistance $\left(\mathrm{C}_{\mathrm{sr}}\right)$ of samples at the age of 28 days on the amount of admixture and its milling fineness (by residue on sieve No. 008).

In order to study the structure of obtained hardened cement paste, samples of Portland cement with $(15 \%)$ and without admixtures were investigated using JEOL JSM-7800F scanning electron microscope, the results are presented in Figure 2. Analysis of obtained micropictures allows making a conclusion that introduction of activated rock sand admixture causes densification of its structure. At the picture with 60 -fold zoom (Fig. $2 \mathrm{a}, \mathrm{b}$ ) the modifying admixture is seen to densify the structure of hardened cement paste.
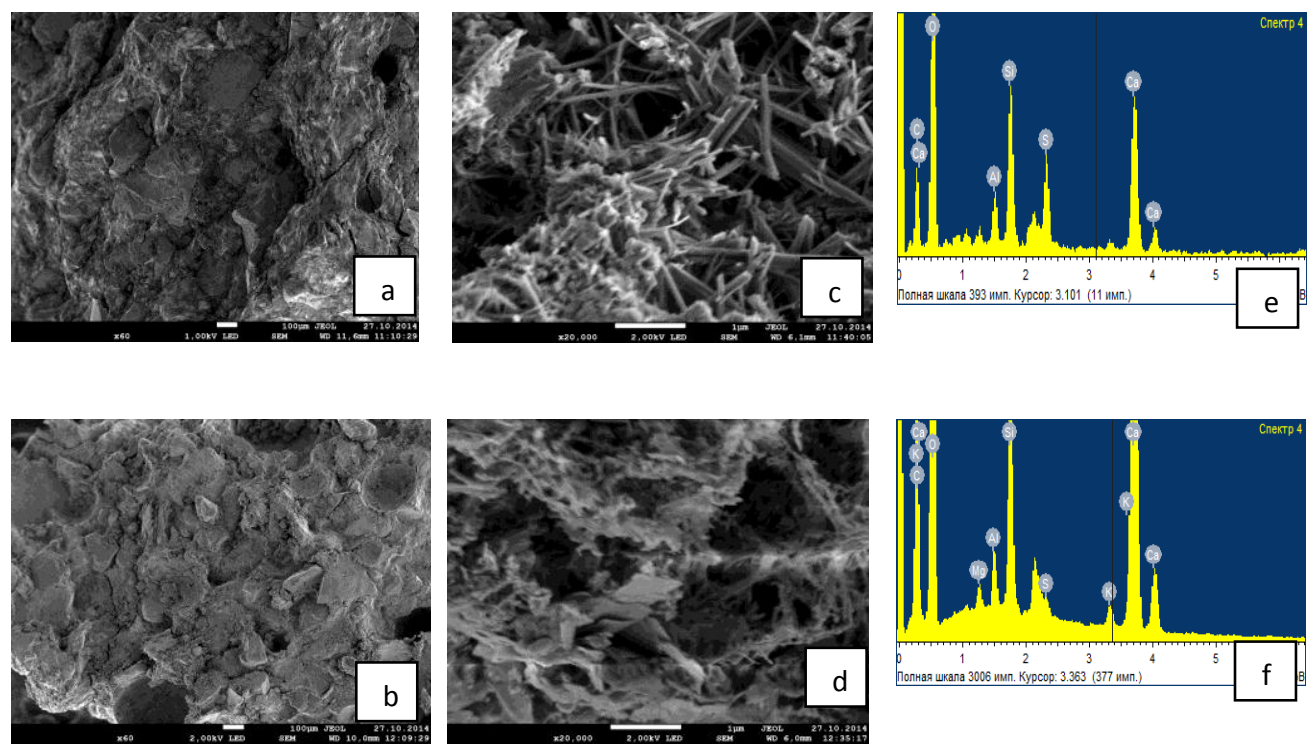

Fig. 2. Micropictures and spectrograms of hardened cement paste without admixture (a, c, e) and with $15 \%$ of admixture (b, d, f): a,b - 60-fold zoom; c, d - 20000-fold zoom, e,f - spectrograms. 
20,000-fold zoom (Fig. 2 c, d) demonstrates the structure of new formations, it is visible that space between structural crystals of hydrosilicate and calcium aluminate sulfate hydrate is filled with other microcrystalline formations, which provides dense and solid hardened cement paste and has positive effect on its strength. Such structure formation can be referred to technogenic metasomatism [17]. Data from spectrograms (Fig. 2 e, f) confirm presence of greater amount of silicates and calcium aluminates in hardened cement paste with activated rock sand.

The influence of the developed admixture on frost resistance properties of hardened cement paste was determined using accelerated method. During the experiment cube specimens with the size of $70 \times 70 \times 70 \mathrm{~mm}$ produced from fine-grained concrete based on Portland cement with optimized amount of rock sand (15\%) activated for 4 minutes were subjected to 20 freeze-thaw cycles with thawing in $5 \%$ water solution of sodium chloride, which corresponds to at least F200 brand of concrete frost resistance.

\section{Conclusion}

Due to adding to Portland cement the developed modifier based on rock sand of Kildyanskoe deposit (Sakha Republic, Yakutia) having quartz-feldspar composition the sulphate resistance coefficient of hardened cement paste was increased up to the value of 1 . This fact proves that local silica raw materials can be used as modifying admixtures to Portland cement. The effect consists in longer service life of concrete structures that operate in harsh climate conditions and aggressive sulphate environments. Besides, the cost of 1 ton of Portland cement with $15 \%$ of the developed admixture is lower by $14 \%$.

Extension of this research can be focused on defining the influence of the developed admixture on durability of concrete products in natural conditions.

This research was supported by the Foundation for Assistance to Small Innovative Enterprises (FASIE), UMNIK program.

\section{References}

1. A.D. Egorova, A.E. Mestnikov, P.S. Abramova, Gornyi Zhurnal [Mining Journal], 9, 65-68 (2016)

2. U.A. Gaziev, Othody promyshlennosti v proizvodstve stroitel'nyh materialov i izdelij [Industrial wastes in manufacture of building materials and products], 23-28 (2015) (in Russian)

3. L.I. Dvorkin, Snizhenie rashoda cementa $i$ topliva $v$ proizvodstve sbornogo zhelezobetona [Reducing of cement content and fuel during the production of prefabricated reinforced concrete], 53-54 (Vyshha shkola, Kiev, 1985) (in Russian)

4. AgroPraktik, Zasolenie pochv: problema i puti reshenija [Soil salinity: problem and solutions], available at: http://agropraktik.ru/blog/1097.html (accessed 07.07.2017) (in Russian)

5. K.A. Akmalaev, M.S. Saduakasov, E.K. Nurmaganbetov, Povyshenie sul'fatostojkosti betonov s primeneniem himicheskih dobavok [Increase of sulphate resistance of concrete by using chemical admixtures], available at: http://elib.kazntu.kz/sites/default/files/articles/akmalaev_2007_2.pdf (accessed 02.08.2017) (in Russian)

6. M.H. Shehata, G. Adhikari, Sh. Radomski, ACI Materials Journal, 6, 594-602 (2008)

7. V.V. Turchin, L.V. Yudina, A.R. Ibatyllina, A.R. Sattarova, Intelligent Systems in Manufacturing, 2(20), 173-179 (2012) (in Russian)

8. GOST 31108-2003. Common cements. Specifications (2016) 
9. TU 5870-005-58042865-05. Specifications, Plasticizer C-3 (Poliplast CP-1)

10. GOST 10178-85. Portland cement and portland blastfurnace slag cement. Specifications (2008)

11. GOST 22266-94. Sulphate resistant cements. Specifications (2014)

12. GOST 8735-88. Sand for construction work. Testing methods (2006)

13. GOST 5802-86. Mortars. Test methods (2010)

14. GOST 10060.0-95. Concretes. Methods for the determination of frost-resistance. General requirements (1997)

15. V.A. Voznesenskiy, T.V. Lyashenko, B.L. Ogarkov, Chislennye metody reshenija stroitel'no-tehnologicheskih zadach na EVM [Numerical methods for the construction and technological tasks on computer] (Vyshha shkola, Kiev, 1989) (in Russian)

16. V.V. Kaymonov, D.V. Vasilyeva, E.I. Protodyakonov, V.A. Andreev, Current issues in construction and life support: safety, quality, energy and resources efficiency, Proceedings of the III All-Russian scientific and practical conference, 268-273 (March 3-4, 2014, Yakutsk, Russia) (in Russian)

17. V.S. Lesovik, I.L. Chulkova, Vestnik SibADI, 4(44), 69-79 (2015) (in Russian) 